\title{
KEBERMAKNAAN HIDUP LANSIA PEMULUNG YANG BERAGAMA ISLAM DI TEMPAT PEMBUANGAN AKHIR (TPA) SUKAJAYA KECAMATAN SUKARAME PALEMBANG
}

\author{
Defi Ardia Ningsih, Iredho Fani Reza, Muhamad Uyun \\ Fakultas Psikologi UIN Raden Fatah Palembang \\ azkiyahdefi@gmail.com, iredhofanireza@gmail.com
}

\begin{abstract}
The elderly are people aged over 60 years and still alive. The meaning of life is something that is considered very important, valuable and give special value for someone so it can be used as study. This study used qualitative study with phenomenological design. The technique that is used to determine of subject in this study is purposive sampling. The total of imformants are 4 elderlies based on the criteria. From the analysis of informant data, the elderly scavenger felt meaningfulness with accept their working circumtances as scavengers in their old age, be grateful and stead fast and feel happiness in life which is affected by life experiences that are always in misery, patience and the majority of environmental factors as scavengers.
\end{abstract}

Keywords: : Elderly Scavenger, Meaning of life

\begin{abstract}
ABSTRAK
Lansia ialah manusia yang berumur di atas usia 60 tahun dan masih hidup. Makna hidup adalah halhal yang dianggap sangat penting dan berharga serta memberikan nilai khusus bagi seseorang, sehingga layak dijadikan Penelitian ini menggunakan penelitian jenis kualitatif dengan rancangan penelitian fenomenologis. Teknik yang digunakan untuk menentukan subjek dalam penelitian ini adalah purposive sampling. Dengan jumlah informan yaitu empat orang lansia berdasarkan kriteria yang telah ditentukan. D ari hasil analisis data informan, lansia pemulung merasakan kehidupan yang bermakna dengan menerima keadaan mereka bekerja menjadi seorang pemulung di umur mereka yang sudah tua, bersyukur dan tabah serta merasakan kebahagian di dalam kehidupan yang dipengaruhi oleh pengalaman kehidupan yang selalu dalam penderitaan, kesabaran, dan faktor lingkungan yang mayoritas sebagai pemulung.
\end{abstract}

Kata Kunci: Lansia Pemulung, Makna Hidup

\section{PENDAHULUAN}

Manusia lahir dan menjalani kehidupan ini bukanlah atas kemauan dan kekuatannya sendiri, tetapi manusia hidup atas kehendak Ilahi Sang pencipta seluruh alam semesta ini. Keberadaan manusia diciptakan Allah swt. bermula dari satu diri yang kemudian diciptakan- Nya pasangan dari padanya. Dari awal keberadaan sepasang jenis manusia maka berkembang menjadi banyak manusia yang terus berlangsung hingga kini, termasuk adanya diri kita sekarang ini.

Menurut Hurlock, salah satu tanda perkembangan manusia yaitu menjadi tua. Usia tua adalah periode penutup dalam rentang hidup seseorang, yaitu suatu periode dimana seseorang telah beranjak jauh dari periode terdahulu yang lebih menyenangkan, atau beranjak dari waktu yang penuh dengan manfaat.

Menurut Jack Botwinick, lansia mengalami penurunan kemampuan dalam beberapa hal, misalnya menurunnya kecepatan dimana hilangnya sel- sel pada sumsum tulang belakang memperlambat gerak refleks. Seseorang yang berusia 80 tahunan berjalan lebih lambat dibandingkan masa mudanya. Penurunan kedua terjadi pada melambatnya proses berfikir. 
Namun demikian, daya tangkap dan kecerdasan lansia tidak berkurang. Orang tua yang sehat tidak akan kehilangan kemampuan memberikan pertimbangan dan berfikir abstrak. Kosakata, keterampilan berhitung, daya nalar, hasil pendidikan, dan pengalamannya akan berfungsi terus sampai ajal menjelang.

Bastaman mengatakan bahwa setiap orang menginginkan dirinya menjadi orang yang bermartabat dan berguna bagi dirinya, keluarga, lingkungan kerja, masyarakat sekitar, dan beharga di mata tuhan.

Setiap orang pasti menginginkan bagi dirinya suatu cita-cita dan tujuan hidup yang penting dan jelas yang akan diperjuangkannya dengan penuh semangat, sebuah tujuan hidup yang menjadi arahan segala kegiatannya. Itulah sekelumit keinginan manusia diantara sekian banyak keinginan lainnya, yang apabila direnungkan yaitu ternyata menggambarkan hasrat yang paling mendasar dari manusia yaitu hasrat untuk hidup bermakna.

Adapun di dalam kehidupan terdapat sumber-sumber dalam kegiatan yang secara potensial mengandung nilai-nilai yang memungkinkan seseorang menemukan makna hidup di dalamnya apabila nilai-nilai itu diterapkan dan dipenuhi.

Menurut Bastaman nilai- nilai tersebut adalah, sebagai berikut:

a. Nilai-nilai kreatif (Creative values). Nilai-nilai kreatif mencakup kegiatan berkarya, bekerja, menciptakan serta melaksanakan kewajiban sebaik-baiknya dengan penuh rasa tanggung jawab. Menekuni suatu pekerjaan dan meningkatkan keterlibatan pribadi terhadap tugas serta berusaha untuk mengerjakannya dengan sebaik-baiknya merupakan salah satu contoh dari kegiatan berkarya. Melalui karya dan bekerja, setiap individu dapat menemukan arti hidup dan menghayati kehidupan secara bermakna.

b. Nilai-nilai penghayatan (Experiential values). Yaitu keyakinan akan nilai-nilai kebenaran, kebajikan, keindahan dan keagamaan serta cinta kasih. Dengan menghayati suatu nilai dapat menjadikan setiap individu berarti dalam hidupnya.

c. Nilai-nilai bersikap (Attitudinal values). Yaitu menerima dengan penuh ketabahan, kesabaran dan keberanian menghadapi segala bentuk penderitaan yang tidak dapat dielakkan lagi.

d. Nilai-nilai harapan (Hope values), keyakinan akan terjadinya hal-hal yang baik atau perubahan yang menguntungkan di kemudian hari.

Menurut Elviana Kaharingan dkk, Lansia yang berhasil menemukan makna hidup, maka mereka dapat menjalani kehidupan dengan penuh semangat dan optimisme, mempunyai tujuan yang jelas baik jangka pendek maupun jangka panjang dan bertanggung jawab baik terhadap diri sendiri, lingkungan atau masyarakat. Dengan demikian, kegiatan-kegiatan mereka menjadi lebih terarah dan menyadari bahwa hikmah selalu ada dibalik penderitaannya.

\section{METODE PENELITIAN}

\section{Jenis Penelitian}

Jenis penelitian ini merupakan jenis penelitian kualitatif dengan pendekatan fenomenologi. metode kualitatif memiliki pengertian ialah suatu metode pengumpulan data dengan lebih menekankan analisisnya pada proses penyimpulan deduktif dan induktif serta pada analisis terhadap dinamika hubungan antar fenomena yang diamati, dengan menggunakan logika ilmiah. 


\section{Informan Penelitian}

Dalam penelitian kualitatif, istilah sampel diganti menjadi subjek, informan, partisipan atau sasaran penelitian.

Dalam hal ini, penulis akan menggunakan istilah informan sebagai sampel penelitian. Teknik yang digunakan untuk menentukan subjek dalam penelitian ini adalah purposive sampling. Purposive sampling adalah teknik pengambilan sample sumber data dengan pertimbangan tertentu. Kemudian orang tersebut dianggap paling tahu tentang apa yang menjadi permasalahan untuk diteliti. Adapun kriteria sampel dalam penelitian ini yaitu:

a. Lansia yang berusia 60 tahun ke atas berjenis kelamin laki-laki dan perempuan.

b. Individu lansia yang beragama Islam.

c. Individu lansia bekerja sebagai pemulung lebih dari 5 tahun di TPA Sukajaya kec. Sukarame Palembang.

\section{Metode Pengumpulan Data}

a. Wawancara

Dalam penelitian ini wawancara dilakukan dengan menggunakan pedoman wawancara semiterstruktur. Menurut Sugiyono wawancara semiterstruktur adalah jenis wawancara yang termasuk dalam kategori in-dept interview, di mana dalam pelaksanaannya lebih bebas bila dibandingkan dengan wawancara terstruktur.

Tujuan dari wawancara jenis ini adalah untuk menemukan permasalahan secara lebih terbuka, di mana pihak yang diajak wawancara diminta pendapat, ideidenya. Dalam melakukan wawancara, peneliti perlu mendengarkan secara teliti dan mencatat apa yang dikemukakan oleh informan.

Adapun materi pedoman wawancara dalam penelitian ini disusun berdasarkan sumber-sumber makna hidup dari Bastaman yaitu nilai-nilai kreatif, nilai-nilai penghayatan, nilai-nilai bersikap, dan nilainilai harapan.

\section{b. Observasi}

Jenis observasi yang digunakan dalam penelitian ini adalah observasi nonpartisipan. Menurut Sugiono, observasi nonpartisipan ialah peneliti tidak terlibat dan hanya sebagai pengamat independen. Peneliti melakukan penjajakan dan eksplorasi ke lokasi penelitian, dan mencari serta memperhatikan apa yang ada. Selain itu, dalam observasi nonpartisipan gejala yang tampak sistematis dan persiapan sehingga hasil yang didapat lebih alamiah.

\section{c. Dokumentasi}

Menurut Sugiyono, Dokumentasi merupakan peristiwa yang sudah berlalu.Dokumen bisa berbentuk tulisan, gambar, atau karya-karya monumental dari seseorang.Dokumen yang berbentuk tulisan, misalnya catatan harian, sejarah kehidupan, ceritera, biografi, peraturan dan kebijakan.Data dokumentasi yang akan digunakan adalah berupa hasil foto, gambar hidup, sketsa dan lain-lain. Dokumen yang berbentuk karya seni, yang dapat berupa gambar, patung, film dan lain-lain.

\section{Metode Analisis Data}

Adapun teknik analisis data dalam penelitian ini menggunakan teknik analisis Miles dan Huberman yang menyatakan tahapan aktivitas dalam analisis data yaitu data reduction, data display, dan conclusion drawing/verification.

a. Data Reduction (Reduksi Data)

Data yang diperoleh dari lapangan jumlahnya cukup banyak, untuk itu maka perlu dicatat secara teliti dan rinci.Mereduksi data berarti merangkum, memilih hal-hal yang pokok, memfokuskan pada hal-hal yang penting, dicari tema dan polanya. Dengan demikian, data yang telah direduksi akan 
memberikan gambaran yang jelas, dan mempermudah peneliti untuk melakukan pengumpulan data selanjutnya dan mencarinya bila diperlukan.

\section{b. Data Display (Penyajian Data)}

Setelah data direduksi, maka langkah selanjutnya adalah mendisplaykan data.Dalam penelitian kualitatif, penyajian data bisa dilakukan dalam bentuk uraian singkat, bagan, hubungan antar kategori, flowchart, dan sejenisnya. Dengan mendisplaykan data, akan memudahkan untuk memahami apa yang terjadi, merencanakan kerja selanjutnya berdasarkan apa yang telah dipahami.

\section{c. Conclusion Drawing/Verification}

Langkah ketiga dalam analisis data kualitatif adalah penarikan kesimpulan dan verifikasi. Kesimpulan awal yang dikemukakan masih bersifat sementara, dan akan berubah bila tidak ditemukan bukti-bukti kuat yang mendukung pada tahap pengumpulan data berikutnya. Dengan demikian, kesimpulan dalam penelitian kualitatif mungkin dapat menjawab rumusan masalah yang dirumuskan sejak awal, tetapi mungkin juga tidak, karena seperti yang dikemukakan bahwa masalah dan rumusan masalah dalam penelitian kualitatif masih bersifat sementara dan akan berkembang setelah peneliti berada di lapangan.

\section{Keabsahan Data penelitian}

Adapun rencana untuk melakukan uji kredibilitas ini yaitu :

\section{a. Perpanjangan pengamatan}

Dengan perpanjangan pengamatan berarti peneliti kembali ke lapangan, melakukan pengamatan, wawancara lagi dengan sumber data yang pernah ditemui maupun yang baru.

b. Triangulasi
Triangulasi dalam pengujian kredibilitas ini diartikan sebagai pengecekan data dari berbagai sumber (triangulasi sumber untuk menguji kredibilitas dengan cara mengecek data yang telah diperoleh melalui beberapa sumber) dengan berbagai cara (triangulasi teknik ini dapat dilakukan dengan cara mengecek antara hasil wawancara dengan hasil observasi), dan berbagai waktu (dilakukan dengan cara melakukan pengecekan wawancara dan observasi dalam waktu dan situasi yang berbeda).

\section{c. Mengadakan Member Check}

Member Check adalah proses pengecekan data yang diperoleh peneliti kepada pemberi data. Tujuan member check adalah untuk mengetahui seberapa jauh data yang diperoleh sesuai dengan apa yang diberikan oleh pemberi data.

\section{HASIL PENELITIAN DAN PEMBAHASAN}

\section{Persiapan Penelitian \\ a. Persiapan Administrasi}

Awal penelitian ini dilakukan dengan melakukan pra penelitian berupa wawancara dan observasi di TPA Sukawinatan pada tanggal 17 Mei 2016, kemudian dilanjutkan dengan persiapan administrasi dalam penelitian ini mencakup surat izin penelitian yang dikeluarkan oleh Dekan Fakultas Ushuluddin dan Pemikiran Islam, dengan nomor: Un.03/III. 1/1351/2016 a.n. Defi Ardia Ningsih pada tanggal 10 oktober 2016 bertepatan dengan tanggal 09 Muharram 1437 $\mathrm{H}$ yang ditujukan kepada walikota Palembang melalui kepala kesatuan bangsa dan politik kota Palembang, setelah itu mendapatkan surat dari badan kesatuan bangsa dan politik dengan nomor: 070/1054/BAN.KBP/ 2016 yang ditujukan kepada camat Sukarami kota Palembang kemudian dilanjutkan dengan dikeluarkannya surat dari kecamatan 
Sukarami dengan nomor: 070/421/SKR/2016 yang dikeluarkan di Palembang pada tanggal 13 oktober 2016 ditujukan kepada lurah Sukajaya di Palembang, dengan itu didapat surat balasan dengan nomor: 070/273/skj//XII/2016 ditujukan kepada ketua RT 68 Rw. 10 kel.

Sukajaya Palembang pada tanggal 17 Oktober 2016. Maka didapat izin penelitian dari tanggal 12 Oktober 2016 - 30 Desember 2016 yang kemudian dilakukan penelitian dari tanggal 28 Oktober 2016 dengan meminta saran dari ketua RT sehingga didapatlah informan sesuai dengan kriteria yang telah ditentukan yaitu informan US, CU, CH dan TM.

Dalam hal ini pertemuan dengan informan untuk meminta izin yang dilakukan oleh peneliti bertujuan untuk meminta kesediaan menjadi informan penelitian agar dapat melakukan wawancara dan observasi dengan tujuan mendapatkan data dalam pelaksanaan penelitian. Berdasarkan izin tersebut, maka informan memberikan izin kepada peneliti dengan menunjukkan kesediaannya tanpa syarat dan sebagai bukti informan memberikan kesediaannya dalam bentuk pernyataan yang ditandatangani oleh informan.

\section{b. Pelaksanaan Penelitian}

Informan penelitian berjumlah 4 (empat) orang lansia pemulung dan informan pendukung berjumlah 4 (empat) orang dan ketua RT jadi jumlah keseluruhan informan 9 (sembilan) orang, informan diambil dengan menggunakan teknik purposive sampling yaitu sampel diambil berdasarkan kriteria dan tujuan tertentu. Pelaksanaan penelitian dengan melakukan observasi, wawancara dan dokumentasi mengenai kebermaknaan hidup lansia pemulung yang beragama Islam di TPA Sukajaya kecamatan Sukarame Palembang dari 17 Mei 2016- 30 Desember 2016.

\section{Hasil Temuan Penelitian}

Sebagaimana telah diuraikan tentang kebermaknaan hidup pada lansia pemulung, dengan jumlah informan berjumlah empat orang yang berinisial US, $\mathrm{CU}, \mathrm{CH}$, dan TM yang telah menetap di TPA Sukajaya lebih dari lima tahun dan menjadi pemulung disana yang berasal dari berbagai daerah.

Dalam hal ini makna hidup yang dirasakan informan merupakan berdasarkan ungkapan Bastaman yang berupa sumbersumber makna hidup yang meliputi nilai-nilai kreatif yaitu kegiatan berkarya, bekerja, menciptakan serta melaksanakan kewajiban sebaik-baiknya dengan penuh rasa tanggung jawab, nilai-nilai penghayatan yaitu keyakinan akan nilai-nilai kebenaran, kebajikan, keindahan dan keagamaan serta cinta kasih. Nilai- nilai bersikap yaitu menerima dengan penuh ketabahan, kesabaran dan keberanian menghadapi segala bentuk penderitaan yang tidak dapat dielakkan lagi seperti sakit yang tidak dapat disembuhkan, kematian dan menjelang kematian, dan nilai- nilai harapan yaitu keyakinan akan terjadinya hal-hal yang baik atau perubahan yang menguntungkan di kemudian hari. Memberikan sebuah peluang dan solusi serta tujuan baru yang menjanjikan, menimbulkan semangat dan optimis.

Nilai-nilai kreatif pada informan US, $\mathrm{CU}, \mathrm{CH}$, dan TM dapat dilihat dari hasil ungkapan mereka yaitu bahwa bekerja yaitu suatu kewajiban dan mencari nafkah untuk kebutuhan keluarga, bahkan informan US merasa tidak malu dengan pekerjaan mulung karena menurut informan bahwa memulung bukan mengambil hak orang lain dan pekerjaan itu halal, dan informan $\mathrm{CU}, \mathrm{CH}$ dan TM awalnya merasa terpaksa dan sedih akan tetapi lama-kelamaan mereka senang menjalani rutinitas memulung dan menerima keadaan hidup mereka dan menurut informan itu adalah takdir kehidupan yang harus mereka jalani. 
Peryataan informan selaras dengan pendapat Frankl tentang asas logoterapi yang mengatakan bahwa hidup itu memiliki makna dalam setiap situasi, bahkan dalam penderitaan dan kepedihan sekalipun. Makna adalah sesuatu yang dirasakan penting, benar, beharga dan didambakan serta memberikan nilai khusus bagi seseorang dan layak dijadikan tujuan hidup. Karena dalam firman Allah telah dikatakan yaitu dalam QS. Alinsyirah ayat 5-6 yaitu:

Artinya: Karena Sesungguhnya sesudah kesulitan itu ada kemudahan, Sesungguhnya sesudah kesulitan itu ada kemudahan.

Dalam ayat ini Allah mengungkapkan bahwa sesungguhnya di dalam setiap kesempitan, terdapat kelapangan, dan didalam setiap kekurangan sarana untuk mencapai suatu keinginan, terdapat pula jalan keluar. Namun demikian, dalam usaha untuk meraih sesuatu harus tetap berpegang pada kesabaran dan tawakal kepada Allah.

Maksud dalam ayat ini yaitu bahwa sesulit apapun dalam menjalani kehidupan ini harus tetap sabar dan tawakal karena suatu saat akan ada kemudahan dibalik itu semua. Dan ayat tersebut menyerukan agar selalu bersyukur, bersabar dan bahagia.

Sedangkan bentuk nilai-nilai penghayatan yang dirasakan informan yaitu keyakinan akan nilai-nilai kebenaran, kebajikan, keindahan dan keagamaan serta cinta kasih. Dimana menurut informan US, $\mathrm{CU}, \mathrm{CH}$, dan TM tentang arti sebuah kehidupan itu bermacam-macam, ada sebuah arti di dalamnya dan ada juga suatu tidak keberuntungan nasib akan tetapi menurut para informan semua itu harus dijalani. Bahkan walaupun dalam kehidupan mereka selalu penderitaan dan kesusahan yang dialami selalu dijalani dengan rasa syukur dan menerima dengan tabah karena itu adalah takdir kehidupan.

Pendapat informan sependapat dengan pernyataan Erickson yang menyatakan bahwa orang yang mencapai integritas diri adalah mereka yang dengan salah satu cara telah mengasuh generasi muda, yang tetap tegar dalam keberhasilan maupun kegagalan yang dialami sebagai orang tua. Integritas ego atau integritas diri merupakan perasaan menjadi bagian daripada tata aturan yang ada dalam alam semesta, perasaan cinta pada sesama manusia dan dengan begitu ikut menimbulkan keteraturan dunia, serta menerima keadaan dirinya sendiri, mensyukuri nasib, dan mencintai orang tua yang menyebabkan mereka ada di dunia.

Selanjutnya, sumber makna hidup ketiga yaitu nilai-nilai bersikap; menerima dengan penuh ketabahan, kesabaran dan keberanian menghadapi segala bentuk penderitaan. Dimana menurut informan US, $\mathrm{CH}$, dan TM mereka merasakan bahagia dengan keadaan hidup mereka yang memprihatinkan, bahkan mereka tidak pernah merasa bahwa hidup itu tidak adil walaupun menurut mereka dengan keadaan mereka yang selalu dalam penderitaan. Hanya saja informan CU mengatakan bahwa ia tidak pernah merasakan kebahagian dalam hidupnya yang seperti itu bahkan ia mengatakan bahwa semua penderitaannya tidak bisa ia ungkapkan dengan kata-kata lagi hanya saja ia menerima bahwa hidupnya memang sudah digariskan seperti itu dan menerima saja sampai ajal menjemput.

Salah satu faktor yang mempengaruhi informan dalam mengatasi permasalahan hidupnya karena pengalaman hidup yang menjadikan mereka untuk bersikap positif dan menerima keadaan, sesuai dengan ungkapan Sarlito tentang sikap yaitu istilah yang mencerminkan rasa senang, tidak senang, atau perasaan biasa-biasa saja dari seseorang 
terhadap sesuatu, sesuatu itu bisa benda, kejadian, situasi, orang-orang atau kelompok. Frankl menambahkan salah satu gejala dari orang yang kehilangan makna hidupnya ditunjukkan dengan perasaan hampa dan merasakan hidup tidak berarti. Walaupun begitu tidak menurut Bastaman, ia mengungkapkan bahwa penderitaan memang dapat memberikan makna dan guna apabila kita dapat mengubah sikap terhadap penderitaan itu menjadi lebih baik.

Oleh karena itu, para informan lebih banyak tabah dan mendekatkan kepada Tuhan, apalagi dengan usia mereka yang sudah tua. Menurut US, CU, CH, dan TM karena mereka sudah tua, dan untuk mengahadapi kematian mereka kelak mereka selau mengerjakan amal ibadah, berzikir, membantu orang lain dan menunaikan sholat waluapun tidak lima waktu karena kondisi yang tidak memungkinkan menurut mereka.

Selanjutnya yang terakhir nilai-nilai harapan yaitu; keyakinan akan terjadinya halhal yang baik atau perubahan yang menguntungkan di kemudian hari. Frankl mengatakan, seseorang harus memiliki alasan untuk meneruskan kehidupan, untuk menyelesaikan tujuan yang akan datang, kalu tidak maka kehidupan akan kehilangan arti.

Kemudian Bastaman mengungkapkan harapan sekalipun belum tentu menjadi kenyataan memberikan sebuah peluang dan solusi serta tujuan baru yang menjanjikan yang dapat menimbulkan semangat dan optimisme. Pengharapan mengandung makna hidup karena adanya keyakinan akan terjadinya perubahan yang lebih baik, ketabahna menghadapi keadaan buruk saat ini dan sikap optimis menyongsong masa depan. Harapan mungkin sekedar impian, tetapi tak jarang impian itu menjadi nyata.

Selaras dengan ungkapan di atas, informan US, CU, $\mathrm{CH}$, dan TM dalam nilai harapan, mereka di usia tuanya berharap diberikan kesehatan, umur panjang, hidup yang rukun dan damai. Mereka tidak merasa putus asa dalam mencari nafkah. Sedangkan untuk cita-cita yang lain seperti mempunyai rumah, kendaraan pribadi dan yang semacamnya mereka sudah pasrah karena menurut mereka umur sudah tidak memungkinkan lagi dan masa itu sudah habis. Berdasarkan uraian diatas dapat disimpulkan bahwa kebermaknaan hidup lansia pemulung yang beragama islam di TPA Sukajaya kecamatan Sukarame Palembang, ke empat informan tersebut sudah menemukan makna hidup mereka dengan cukup baik. Sejalan dengan hasil penelitian yang dilakukan oleh peneliti sebelumnya yang menunjukkan hasil penelitian menyatakan bahwa kedua subjek memaknai kehidupan dengan berbeda. Subjek I sedang melakukan proses yang baik untuk mencapai makna hidupnya dengan bekerja sebisa mungkin dalam kondisinya yang memiliki hambatan ekonomi demi istri dan anaknya.

Sedangkan subjek II memaknai kehidupannya sebagai kehidupan yang biasa saja dan merasa nyaman dengan kondisinya saat ini sehingga ia kurang menjalani proses lebih untuk mencapai makna hidup.Namun ia merasa bahagia ketika bersenang-senang dengan temannya. Perbedaan ini dipengaruhi oleh status subjek, karena berkaitan dengan peran dan tanggung jawab yang harus dipenuhi, dan tipe skizorenia yang diderita subjek.

\section{SIMPULAN}

Dari hasil penelitian ini dapat disimpulkan bahwa faktor lansia memulung karena tidak punya pekerjaan lain, sedangkan keahlianpun mereka tidak ada. Oleh karena tuntutan ekonomi dan menghidupi keluarga mereka terpaksa memulung karena menurut mereka pekerjaan memulung adalah pekerjaan halal dan tidak tergantung dengan orang lain serta bersifat fleksibel tidak terikat 
waktu kapanpun mereka ingin bekerja dan beristirahat.

Sedangkan kebermaknaan hidup lansia pemulung diwujudkan dengan cara menerima keadaan mereka yang bekerja sebagai seorang pemulung di umur mereka yang sudah tua, selalu bersyukur dan tabah serta merasakan kebahagian di dalam kehidupan dan selalu semangat dalam bekerja di usia mereka yang sudah tua. Kebermaknaan hidup lansia pemulung dipengaruhi oleh beberapa faktor yaitu antara lain: a) pengalaman kehidupan yang selalu dalam penderitaan dan penuh kesulitan dalam ekonomi, b) kesabaran lansia pemulung yang menerima keadaan sebagai pemulung, dan c) yaitu faktor lingkungan mereka yang mayoritas sebagai pemulung.

\section{DAFTAR PUSTAKA}

Azwar, Syaifuddin. Metode Penelitian. Yokyakarta: Pustaka Pelajar. 1998

Baihaqi, Mif, Psikologi Pertumbuhan : Kepribadian Sehat Untuk Mengembalikan Optimisme, Bandung, PT. Remaja Rosdakarya, 2008

Bastaman, H.D, Logoterapi : Psikologi Untuk Menemukan Makna Hidup Dan Meraih Hidup Bermakna. Jakarta: Pt. Raja Grafindo Persada. 2007

F. J. Monks dan A. M. P. Knoers, Ontwikkelings Pshychologie Inleiding tot de Verschillende Deelgebieden, diterjemahkan oleh Siti Rahayu Haditono, Psikologi perkembangan: Pengantar dalam berbagai bagiannya, cet. XVII Yogyakarta, Gajah Mada University Press, 2014

Halim, Deddy K. Psikologi Lingkungan Perkotaan. Jakarta: Bumi Aksara. 2008

Hurlock, Elizabeth B. Development Psychology A Life Span Approach, Fifth Edition. Diterjemahkan oleh Istiwidayanti dan Soejarwo. Psikologi Perkembangan Suatu Pendekatan
Sepenjang Rentang Kehidupan. Jakarta: Erlangga. 2009

Joko Suharto Bin Matsnawi. Menuju Kemenangan Jiwa. Jakarta: Rineka Cipta. 2007

Kaharingan, Elviana, Hendro Bidjuni dan Michael Karundeng. Pengaruh Penerapan Terapi Okupasi Terhadap Kebermaknaan Hidup Pada Lansia Di Panti Werdha Damai Ranomuut Manado. Ejournal Keperawatan (EKp), Vol 3 No 2, 2015

Kementerian Agama RI. Al-Quran Dan Tafsirnya : Jilid 7 Juz 19-21. Jakarta:

PT. Sinergi Pustaka Indonesia. 2012

Moleong, Lexy J. Metodologi Penelitian Kualitatif. Bandung: PT Remaja Rosdakarya. 2013

Poerwandari, Kristi. Pendekatan Kualitatif Untuk Penelitian Perilaku Manusia. Jakarta: LPSP3 UI. 2011

Safaria, Triantoro, Manajemen Emosi, Jakarta, Bumi Aksara, 2006

Sarwono, Sarlito W. Pengantar Psikologi Umum, Jakarta, PT Raja Garfindo Persada, 2010

Sugiyono, Memahami Penelitian Kualitatif, Bandung,: ALFABETA, 2005

Metode penelitian Kuantitatif dan Kualitatif dan R \& D. Bandung: Alfabeta. 2014 